(c) 2016

\title{
Molecular-genetic features of enteroviruses of pigs
}

\author{
V. Romanenko, \\ Academician of the NAAS, Doctor of Veterinary Sciences \\ Institute of Veterinary Medicine, NAAS
}

The purpose. To sum up results of long-term molecular-genetic probes of enteroviruses of pigs, their scientific and practical importance. Methods. Methods of analysis, consolidation and systematization are used. At probe of enteroviruses of pigs they used virologic methods. Results. As a result of study of antigenic properties of excreted enteroviruses, using collection of reference strains of Laboratory Pirbright, they revealed 14 new, before unknown, serotypes of enteroviruses of pigs, reference strains of which are protected by copyright certificates of the USSR. The results gained testify to the following: division by XI International congress on virology of enteroviruses of pigs on 2 genuses - Enterovirus and Teschovirus is unreasonable and does not meet a reality. Conclusions. On the basis of the gained results the laboratory of immunogenetics of enteroviruses of pigs of Institute of veterinary medicine of NAAS has the right to troubleshoot enterovirus sicknesses of pigs, in particular Teshen sickness of pigs for what they developed sets of diagnosticums. The vaccine is developed for prophylaxis of enzootic encephalomyelitis (Teshen sickness) of pigs against Teshen sickness of pigs.

Key words: molecular-genetic probes, enteroviruses of pigs, grading of enteroviruses, sets of diagnosticums, virus-vaccine against Teshen sickness.

The purpose of the research is to summarize the results of long-term molecular genetic studies of porcine enteroviruses, their scientific and practical significance. Research methods. Methods of analysis, generalization and systematization are used. During the study of enterovirus pigs, virological methods were used. Research results. For the first time in 1929, L. Trefni informed about the enterovirus disease of pigs enzootic encephalomyelitis (infectious paralysis of pigs), which is similar to human poliomyelitis. $\mathrm{He}$ discovered an outbreak of disease in a pig farm near the town of Tezen near the Czech-Polish border and called - Teschen disease.

The enzootic encephalomyelitis virus is enrolled to the 1st serotype of the enteroviruses of pigs, whereas in the disease of the porcine enteroviral pneumonia involved enteroviruses of the 2nd, 3rd, 4th, 5th, 8th, 14th, 16th and 17th serotypes, and enterovirus gastroenteritis - 2, 3, 4, 5, 6, 8, 10, 11, 12, 13, 14, 19 and 20 serotypes (V.P. Romanenko, 1982; V.P. Romanenko with singing., 1993, 1994). This is not just the case with the enteroviruses of pigs. According to MK Voroshilova (1979), in humans, enteroviruses, in addition to poliomyelitis syndrome, cause poliomyelitis-like diseases: aseptic meningitis and encephalitis, epidemic myalgia, myocarditis and pericarditis, encephalomyelitis newborns, gerpangina, epidemic hemorrhagic conjunctivitis, respiratory and gastrointestinal disorders, as well as general febrile illness.

M.K. Voroshilov also emphasizes that one and the same virus can cause several clinical syndromes, and vice versa, each of the inherent syndromes can be caused by enteroviruses of several serotypes. Enterovirus is also very common among healthy people. A similar phenomenon is observed in pigs diseases etiologically predetermined by enteroviruses, although not with such a wide discovery of the role of enteroviruses in pig disease, which is largely due to the recent beginning of the study of these problems.

M.P. Chumakov, I.M. Prisman, T.S. Zatsepin (1953) and M.K. Voroshilov (1966) emphasize that the reports of people with poliomyelitis have long been the subject of poliomyelitis, and the polio virus was first isolated in 1908 by K. Landsteiner, E. Popper and studied in subsequent years.

The first report on the cultivation of enteroviruses of pigs was made by A. Betts (1966), P. Lamont (1960), M. Sibalin (1960), then this issue was studied by other researchers who established the biological, physicochemical, morphological, genetic and other properties of enteroviruses pigs [8 - 10].

Identified by various researchers, the properties of porcine enteroviruses were summarized by J. Pette (1966), who recommended that only viral nature agents be considered as ECSO viruses, which: 
- have a special affinity for the digestive tract, where they originally multiply;

- have a pronounced cytopathic effect in the culture of pig kidney cells;

- have a size of viruses no more than $30 \mathrm{~nm}$;

- exhibit resistance to chloroform;

- Stable in a wide range of $\mathrm{pH}$ values;

- relatively heat-resistant, and their heat resistance rises for machining with cations $\mathrm{Mg} \mathrm{++}$ and $\mathrm{Ca}++$;

- resistant to the action of trypsin;

- Hold RNA [11].

Successful application of cultures of cells for the reproduction of polioviruses by J. Enders, T. Weller, F. Robbins (1949) has made it possible to isolate a large number of previously unknown types of viruses from different organs of humans and animals, in particular pigs. Most viruses were isolated from fecal samples. In most cases, viruses isolated from pigs multiplied in the primitive-trypsinized pig kidney cells (PPS) with the detection of a well-expressed cytopathic action (CPR).

The nature of cytopathic changes caused by enteroviruses of pigs in cell cultures was not the same for all strains of viruses. Thus, according to A. Betts (1960), A. Jennings, D. Kelly, A. Betts (1962), in the case of infection of cell cultures with enteroviruses T-80 and T-52A, the affected cells were initially swollen, some cells at this stage become round. Later the majority of cells were struck, the rounding of the cells, which began to thin out the glass, became more pronounced. Dedicated by R. Lamont and A. Betts (1960), the enterovirus (strain V13) caused less crowding of cells and swelling of the nucleoli in the affected cells. In studying more than 200 isolates of viruses isolated from pig faeces, R. Zoletto $(1964,1965)$ divided them into 3 types:

Type I - the formation of round cells that strongly refract light and grouped in the center of culture;

II type - the appearance in the infected monolayer of cells that strongly refract light and have characteristic protrusions of the cytoplasm;

The third type is the appearance of light-refracted rounded cells infected in a contaminated monolayer.

K. Kadoi, S. Kobiori, T. Morimoto (1970) divided the studied enteroviruses of pigs by type of CPS on 2 types. The enterovirus type I strains caused CPR, which was characterized by hyperchromias of the nucleus, shrinking cytoplasm, rounding, aggregation, and then destasction of the affected cells. Cultures of cells infected with strains causing Type II degeneration had a picnotic nucleus, a shriveled cytoplasm with protrusions, granulated and disintegrated.

E. Pleva, E. Mesaros (1968) was cultured in PPP cell cultures and studied the character of CPR 17 strains of enteroviruses isolated from them by pigs and 8 typical strains obtained from different places. In these experiments, the authors used both the primary cultures of the kidneys of embryos of pigs and the transfused PK line. The nature of the CSP was the same in cells of both types. The TPD of viruses was detected up to $24 \mathrm{~h}$ after infection and was characterized by rounding of cells and thickening of the cell membrane. Sometimes other changes were observed: the boundaries of the cell membrane became blurred and the cytoplasm was leaked into the intercellular space in the form of drops. At the same time, the cell surface becomes toothed. By the end of the 3rd day there was a complete degeneration of cells with their shedding of glass.

Both types of CSFs can be observed simultaneously in the same culture of cells in case of infection by the same strain.

The authors do not consider it possible to classify the isolated enteroviruses of pigs by type of CSF. Similar data were obtained by us (V.P. Romanenko, 1977).

In our experiments, the character of the CSP of enteroviruses in the case of an infectious dose of 1000 to 10,000 viral particles was the same type, regardless of the strain and typical membership in the cultures of the cells PPS and SPEV. CPR occurred mainly after $16-20$ years after infection, in some strains - in $36-40$ hours and was characterized by the appearance of tricks of rounded cells, and after $4-6 \mathrm{~h}$ there were up to $50-70 \%$ of monosacral cells. The rounded cells were granular and had an increased optical density.

The TSP resulted in the complete destruction of the cell monolayer. For the use of SVV cultures for infecting these massive doses of viruses $\left(10^{6}-10^{7} T P D_{50}\right)$, the CSF is manifested by the rounding of infected cells. 
The given data testify that the division of enteroviruses according to the type of CSF is unjustified, as evidenced by experiments by E. Pleva, E. Mesar s, and also by our numerous experiments.

The first classification of the enteroviruses of pigs was performed by A. Betts (1962), who initially divided the enteroviruses into 9 antigenic serogroups, and then T. Alexander, A. Betts (1967), by cross-linking neutralization, divided the enteroviruses studied by them into 10 serologic groups.

In the early 70's, H. Dunne, I. Wang, E. Ammerman at the Pirbright Laboratory (UK) conducted a comparative study of the enterovirus strains of swine from different countries: 13 strains in Great Britain, 5 in Canada, 13 in Canada; USA: from California - 3, Maryland - 6 and Pennsylvania - 32 (1971, 1972). These strains were divided into 8 serogroups: 1st serogroup - strains Teschen, Talfan, Konratice; 2nd - T-80, T52A, F59; 3rd - F34; 4-th - F78; 5th - F12; 6-th - F7; 7th - F43; 8th - V13.

This classification is used in the study and classification of enteroviruses isolated from pigs, in particular in our experiments.

Derived from J. Derbyshire (Pirbright Laboratory, UK) in 1970, the collection of strains of 8 serotypes was the main during the study and classification of the strains of enteroviruses of our pigs isolated on the territory of Ukraine, the Russian Federation and Moldova.

As a result of the study of the reproductive properties of 850 isolates isolated by us, 100 strains were selected, in which, in addition to reproductive properties, resistance to chloroform, ether, trypsin and to media with different $\mathrm{pH}$ values was studied; heat resistance; the effect of nucleic exchange inhibitors on the reproduction of porcine enteroviruses in cell cultures; the ability to spray and the nature of the plaque; morphology of viral particles, as well as their antigenic properties.

As a result of the study, the viruses were enrolled to the genus Enterovirus, the species Enterovirus suis. The properties of porcine enteroviruses revealed by us are fully consistent with the generalized data of $\mathrm{J}$. Pette (1966) on the biological, physico-chemical and genetic properties of porcine enteroviruses, and also correspond to the properties of enteroviruses of humans (M.K. Voroshilova, 1979).

As a result of studying the antigenic properties of isolated enteroviruses, with the use of a collection of reference strains of the Pirbright Laboratory, 14 new (previously unknown) serotypes of enteroviruses of pigs were identified, the reference strains of which are protected by the copyright certificates of the USSR.

The collection of enteroviruses, which includes reference strains of serotypes 1-8, obtained from the Pirbright Laboratory, and 14 referent strains, consists of 23 serotypes (Table 1).

Rasmussen (1969) in Denmark divided the isolated enteroviruses into 10 serotypes. S. Christov (1966) isolated in Bulgaria enterovirus has counted up to three serotypes. We did not find any subsequent communications about these classifications.

In 1979, N. Knowles, L. Buckley and H. Pereira supplemented the collection of enteroviruses of pigs that were included in the Pirbright Laboratory collection as 9th, 10th and 11th serotypes of enteroviruses. In 1990, E. Honda, A. Kimata, I. Hattori, T. Kumagai, T. Tsuda, T. Tokui, and in 1993 J. Auerbach, K. Witte discovered a number of new serotypes of enteroviruses of pigs that were studied only in the neutralization reaction, and not included in the collection of enteroviruses of pigs in Pirbright Laboratory. Materials from the laboratory identification of enteroviruses of pigs were presented in 1994 by $\mathrm{N}$. Knowles at the International Symposium on Pig Nosocomial Infections (Greitswald, Germany, May 2-3, 1994).

And already in 1997, on the Internet, N. Knowles reported "Molecular identification of porcine enteroviruses with the question: are really teratogenic viruses an enteric virus?". The author reports that he has been sequencing the genome of enteroviruses of pigs of 8-, 9-, and 10th serotypes (other serotypes were not subjected to sequencing), and he concluded that they are related to the enteroviruses of humans and animals, while the representatives of other serotypes are not typical enteroviruses for the following reasons:

- Thermal resistance: Group I viruses are not inactivated when heated at $50^{\circ} \mathrm{C}$ for 1 hour, as is the case with true enteroviruses;

- The effect of ions: usually enteroviruses are protected from inactivation at $50^{\circ} \mathrm{C}$ in the presence of $1 \mathrm{M}$ $\mathrm{MgCl}$. Viruses of group I when heated to $50^{\circ} \mathrm{C}$ in the presence of halide ions are inactivated. In this they are similar to the encephalomyocarditis virus, which is inactivated by the heating and presence of halide ions at a certain $\mathrm{pH}$ range; 
- sensitivity to formaldehyde. Treatment with $0.1 \%$ formaldehyde leads to a violation of the structure of the group I viruses, but not II and III;

- During the electron microscopy, viral particles are inflated;

- Growth properties, type of CSF: time required for the emergence of CPS for the dose of inoculation 100 TCD50 - 4-5 days. It is slower than most enteroviruses. Group I differs from the CPS from Groups II and III.

Based on the data presented, N. Knowles reported that the viruses of the CPR I group (serotypes 1 - 7 and $11-13$ ) do not belong to the genus of enteroviruses.

This message to $\mathrm{N}$. Knowles in 1999 was ratified by mail order of the members of the Executive Committee on Taxonomy of Viruses (ICTV) and the same year approved by the XI International Congress on Virology: "Rename enteroviruses of pigs of group I as Teschovirus pigs and isolate into a new generation of Teschovirus, which becomes the 9th birthday in the Picornaviridae family. " The prototype strain of the newly established N. Knowles and approved by the XI International Congress on Virology of the new genus Teschovirus is the Talfan strain that etiologically causes polyencephalomyelitis only in young piglets and is called Talfan's disease, which ends lethally in $20 \%$ of diseased animals, whereas the Teschen disease, a prototype strain which is a strain of Tesch $n$, affects pigs of all age groups, the course of the disease in acute form and ends lethally in $85-95 \%$ of diseased animals.

Is the introduction of the separation of enteroviruses of the two genera of Enterovirus and Teschovirus from the reality?

Based on the current classification developed by the International Committee on the nomenclature of viruses, porcine enteroviruses belong to the genus Enterovirus and should have certain biological, physicochemical, morphological and genetic properties, whereas in N. Knowles materials proposed by ICTV as determining the new genus viruses in the Picornaviridae family, no data on biological and genetic properties, they do not meet the requirements that determine the generic nature of the viruses. Proposed N. Knowles ICTV to determine the new type of virus properties include only some of the physicochemical properties of viruses, which, moreover, are different from those of other researchers. In addition to the above-mentioned data on the reproductive properties of porcine enteroviruses in renal colonies of embryonic pigs, the enteroviruses we studied were resistant to the action of chloroform, ether and trypsin, to media with $\mathrm{pH}$ values $\mathrm{pH} 2$ to 11 , relatively heat-resistant at warming at $56^{\circ} \mathrm{C}$ for 1 hour. Moreover, their thermal stability increased significantly in the presence of $1 \mathrm{M} \mathrm{MgCl} 2$, they created homogeneous, well-defined, matte, round with flat edges of the plaque, RNA-retaining.

During the study of the morphology of the Konratice strain of the Teschen disease virus and the 2 field strains of the enteroviruses of the pigs, a cluster of extracellular virions was found.

The diameter of the virions is $260-270 \quad(26-27 \mathrm{~nm})$, the capsid is 50 . Electron microscopic experiments have established their morphological identity with the enteroviruses of humans and animals (V.P. Romanenko, 1977).

After the 1997 announcement, N. Knowles, "Molecular identification of porcine enteroviruses in the form of a question - are indeed tertiary viruses being enteroviruses?" We conducted repeated experiments on the study of cytopathogenic properties and thermosensitivity of 23 reference strains of porcine enteroviruses in our collection, which includes English reference strains The 1st to 8th serotypes received by us in 1970 from J. Derbyshire, which are constantly used in our studies, and also used in the experiments of N. Knowles.

The results of cytopathic activity of the reference strains of enteroviruses of pigs in the digestive line of cages of kidney embryonic stem cells (SPEV) in three consecutive passes without clearly defined infectious doses used in the experiments of strains of the viruses (Table 2), as well as in the culture of these cells per dose of infection of 100 TCD50 (Table 3).

The results of the thermal resistance of reference strains of enteroviruses of pigs, which were determined by titration of viruses in the culture of cells SPEV unheated (control) and warmed up at $56^{\circ} \mathrm{C}$ for 1 hour without and in the presence of $1 \mathrm{M} \mathrm{MgCl} 2$ (Table 4), are given.

Data tab 2 and 3 indicate that the reference strains of enterovirus pigs, in particular 1-8 serotypes with which $\mathrm{N}$. knowles experiments conducted cause cytopathic changes in cell cultures as infected with an uncontrolled dose, and for inoculation of cultures with 100 DTD50 doses, in a day, and not after 4-5 days, according to $\mathrm{N}$ Knowles. 
Listed in tab. 4 results of our study of the thermosensitivity of porcine enteroviruses indicate that in warmed reference strains at $56^{\circ} \mathrm{C}$ for $1 \mathrm{~h}$ without $1 \mathrm{M} \mathrm{MgCl} 2$ there was a slight decrease in titres compared to control, and in the presence of $1 \mathrm{M} \mathrm{MgCl} 2$ virus titers were almost identical with the titres of control, unheated samples viruses

The results of our many years of research, from 1969 to the present, to the study of the enteroviruses of pigs, in particular the experiments conducted in 2008, ie, after the announcement of $\mathrm{N}$. Knowles and the decision of the XI International Congress on Virology, show that the strains of enteroviruses studied and classified by us pigs, in particular the English reference strains of enteroviruses of serotypes 1 through 8 , obtained from us in 1970 by J. Derbyshire, also investigated by N. Knowles, are enteroviruses belonging to the family Picornaviridae of the genus Enterovirus, the genus Enterovirus suis. The results obtained by us show that the separation of the XIth International Congress on Virology with N. Knowles's offer of enteroviruses of porcine for 2 genera - Enterovirus and Teschovirus is ungrounded and does not correspond to reality.

Moreover, the name of the genus can not be derived from the name of the settlement Tezen, which was first discovered in 1929 by L. Treffney enzootic encephalomyelitis of pigs. In 1933, under the name of Teschen's disease, he described in detail A. Klobuk, she has many synonyms, in particular, polio swine (Denmark). As is well-known, the polio virus, which has 3 serotypes, from which the disease virus of Tetanus pigs differs only by the specific, antigenic and pathogenic properties, is enrolled in the genus Enterovirus and occupies 3 first positions in the classification of enteroviruses in humans.

\section{Conclusions}

On the basis of the results obtained, the laboratory for the immunogenetics of porcine enteroviruses of the Institute of Veterinary Medicine of NAAS is able to diagnose enterovirus diseases of pigs, in particular the Teschen disease, for which sets of diagnostic kits were developed: a set of diagnostic kits of enzootic encephalomyelitis (Teschen disease) for neutralization reactions; Diagnostic Kit for Enzootic Encephalomyelitis (Teschen diseases) for immunofluorescence. Both sets, as well as a vaccine against disease Tsetse of pigs are re-registered by the State Department of Veterinary Medicine of Ukraine July 06, 2010 Registration certificates are valid until 05.07.2015. These sets of diagnosticums are developed, assembled and can be used for the diagnosis of enzootic encephalomyelitis (Teschen disease) of pigs. To prevent enzootic encephalomyelitis (Teschen disease) pigs have been invented a vaccine strain of Perechynsky-642, on the basis of which a vaccine against Teschen disease has been developed. Vaccine strain and vaccine are protected by copyright certificates of the former USSR. The vaccine has been introduced into production by order of the Ministry of Health of the USSR No. 1 of January 17, 1984, and in 1993 the vaccine was issued to VP. Romanenko Patent of Ukraine № 931. The vaccine is worked out, is composed, can be delivered on request of production.

We have established the disease of the pigs by enterovirus pneumocystolitis, which was approved in 1978 by the MGM MSG of the USSR as a new nosological unit. For the eradication of the disease Tsetin pigs were developed and approved initially by the MSR of the MSG of the USSR in 1978, and then by the MGS of the MSG of Ukraine in 2000 and with the requirements of the MEB developed and submitted to the Committee on Veterinary Medicine of Ukraine in 2011, "Instruction on measures for prevention and fighting enzootic encephalomyelitis (Teschen disease) of pigs. "

For the diagnosis of enterovirus gastroenteritis of pigs, "A set of diagnostic chambers of enterovirus gastroenteritis of pigs" (Patent dated December 15, 1993, No. 3687-XII) was developed. On request, it can be developed, compiled and offered for the diagnosis of enterovirus gastroenteritis of pigs.

A set of diagnostic kits for enzootic encephalomyelitis (Teschen disease) and porcine immunization of a vaccine against enzootic encephalomyelitis (Teschen disease) of pigs included in the list of development that exceeds the best world's analogs or is consistent with their technical and economic indicators.

\section{Bibliography}

1. Voroshilova M.K. Development of concepts en evolution of enteroviruses and diseases caused by them/M.K. Voroshilova//Fourth Intern. Cong. for virology, 1978. — P. 620. 
2. Betts A.O. Studies on enteroviruses of pigs $\mathrm{I}$. The recovery in tissue culture of two related strains of swine polioencephalomyelitis virus from the tonsils of «normal

» pigs/A.O. Betts, A.R. Jennings, D.F. Kelly//Res. Vet. Sci. - 1960. — V. 1, № 1. - P. 57 - 75.

3. Alexander H.E. Summary and revtena of papera on «Poliomyelitis virus variation»/H.E. Alexander//Ann. №. 4. Acud. Sci. - 1955. - V. 61, № 6. - P. $940-942$.

4. The isolation and characterisation of some enteroviruses from pigs/A.O. Betts, D.F. Kelly, P.H. Lamont, B.E. Shefty//Vet. Red. — 1961. - V. 73, № 31. - P. $752-755$.

5. Pette J. Derzeitiger Stand unserer Konntnisse ber die ECSO-Viren/J. Pette//Berl. und M nch. Tier rztliche Wochenschr. - 1966. - V. 79, № 1. - S. 6- 10.

6. Dunne H.W. Classification of North American porcine enteroviruses: a comparison with Europian and Japanese strains/H.W. Dunne, T.J. Wang, E.H. Ammerman//Infect. Immunol. — 1971. — V. 4, № 5. - P. $619-631$.

7. Romanenko V.P. Vydilennya enterovirusiv vid svyney v deyakykh zonakh URSR/V.P. Romanenko, O.H. Prus, V.M. Chaus//Visn. s.-h. nauky. — 1973. — № 2. — S. 99 - 101.

8. Romanenko V.F. Rol' эnterovyrusov v patolohyy svyney/V.F. Romanenko//Visnyk s.-h. nauky. — 1974. № $7 .-$ S. $96-101$.

9. Эnzootycheskyy эntsefalomyelyt svyney (bolezn' Teshena)/V.F. Romanenko, N.S. Katasonov, Yu.Y. Petryshche, Y.V. Shvab//Veterynaryya. — 1974. — № 2. -

S. $61-62$.

10. Romanenko V.P. Epizootolohiya enterovirusnykh khvorob svyney/V.P. Romanenko, V.P. Opanasenko//Visn. s.-h. nauky. - 1975. - № 3. - S. $92-94$.

11. Romanenko V.F. Vyrusnыe hastroэnterytы svyney/V.F. Romanenko//Veterynaryya. — 1975. — № 4. S. $47-49$.

12. Romanenko V.F. Yzuchenye shtammovыkh svoystv эnterovyrusov v reaktsyy neytralyzatsyy na kul'ture kletok/V.F. Romanenko//Tr. Vsesoyuz. hos. nauch.-kontr. yn-ta vet. preparatov. - M., 1975. - T. KhKhll . - S. $55-59$.

13. Romanenko V.F. Molekulyarno-henetycheskaya ydentyfykatsyya эnterovyrusov svyney/V.F. Romanenko//Veterynaryya. - 2009. — № 12. - S. 8 - 14.

14. Knowles N.J. Arch. Virol/N.J. Knowles, L.S. Buckley, H.G. Pereira. - 1979. — V. 62, № 3. - P. 201 208.

15. Romanenko V.F. Ynstruktsyya o meropryyatyyakh po bor'be s эnzootycheskym эntsefalomyelytom (bolezn'yu Teshena) svyney/V.F. Romanenko//Veterynaryya. — 1979. — № 2. — S. 35 - 37.

16. Romanenko V.F. Metodycheskye ukazanyya po laboratornoy dyahnostyke эnterovyrusnoho hastroэnteryta svyney/V.F. Romanenko. - M.: MSKh SSSR, 1978. - $25 \mathrm{~s}$.

17. Romanenko V.F. Dyahnostyka y merы bor'bы s эnzootycheskym эntsefalomyelytom (bolezn'yu Teshena) svyney/V.F. Romanenko//Veterynaryya. — 1979. — №2. — S. 35 - 37. 